\title{
Місце клінічних і діагностичних досліджень акантолітичного пемфігусу
}

\author{
I.O. Олійник, А.E-C.E-C. Абдалла \\ ДУ «Інститут дерматології та венерології НАМН України»
}

\begin{abstract}
Резюме
В статті наведено випадок вульгарної пухирчатки, клінічна картина захворювання, методи дослідження та лікувальна тактика.

Ключові слова: вульгарна пухирчатка, перебіг, діагностика, терапія.
\end{abstract}

DOI: 10.33743/ 2308-1066-2019-3-41-43

До групи автоімунних бульозних дерматозів належать наступні види шкірних захворювань: справжня акантолітична пухирчатка; бульозний пемфігоїд; порушення шкіри при алергічних і вірусних захворюваннях шкіри, інші бульозні порушення шкіри (субкорнеальний пустульозний дерматит, герпетиформний дерматит) [3]. Клінічна схожість у цій групі дерматозів спостерігається лише за рахунок формування пухирів у результаті втрати міжклітинного зв'язку. Патогенетичний ланцюг обумовлений формуванням автоантитіл до структурних протеїнів дермо-епідермальних, субепітеліальних зв’язків, що має велике значення для диференціації розташування пухира й забезпечує характеристики, специфічні для певного дерматозу [1].

Групу акантолітичних бульозних дерматозів становлять наступні клінічні форми: вульгарна пухирчатка, себорейна (еритематозна), листоподібна (ексфоліативна) та вегетуюча. Для кожної з них характерні клінічні симптоми: симптом Нікольського І ступеня - по периферії ерозій залишаються обривки покришки пухиря; якщо потягнути за неї, то епідерміс відшаровуватиметься і на видимо здоровій шкірі; симптом Нікольського II та III ступеня в разі потирання шкіри між двома пухирями та на віддалених від висипів ділянках теж відбувається відшарування епідермісу; симптом Асбо-Хансена - під час натискання на пухир предметним склом спостерігається збільшення його площі за рахунок наступного відшарування епідермісу пухирною рідиною; симптом Шеклакова, або феномен «груші», - під вагою рідини в пухирі, в разі вираженого акантолізу, площа його основи збільшується і пухир набуває грушоподібної форми [5].

Важливо зауважити, що хворим з акантолітичним пемфігусом протипоказані рентгенологічне обстеження, ультрафіолетове опромінення, застосування $\beta$-блокаторів, нестероїдних протизапальних засобів, антибіотиків пеніцилінового та цефалоспоринового ряду. Нехтування цих застережень призводить до загострення дерматозу навіть на підтримувальній терапії [4].
Серед перерахованих форм найчастіше зустрічається вульгарна пухирчатка. Для цієї форми характерний початок захворювання з ураження слизової оболонки ротової порожнини. Первинним елементом є в'ялий пухир з тонкою покришкою, що виникає на видимо здоровій слизовій, залишає ерозивні ділянки. Інтактне дно ерозій має яскраво-червоне забарвлення та кровоточить. У випадку приєднання вторинної інфекції дно ерозії вкривається білим, біло-жовтим або сіруватим нальотом. Обмежена локалізація дерматозу на слизовій оболонці може тривати декілька місяців. Поширення процесу відбувається через місяці, вражаються найрізноманітніші ділянки шкірних покривів.

Як на слизовій, так і на шкірі формується в'ялий пухир на видимо здоровій шкірі, наповнений серозним умістом. Пухирі швидко втрачають цілісність і лишають після себе ерозивні або виразкові дефекти. Генералізація шкірного процесу супроводжується порушенням загального стану (слабкістю, гіпертермією, кахексією тощо). Ще на етапі враження слизової оболонки необхідно проводити диференційну діагностику зі стоматитами різноманітного етіологічного характеру (мікотичного, бактеріального чи вірусного). Шкірний процес треба диференціювати з іншими бульозними дерматозами, бульозною токсикодермією, піодермією, мікробною екземою.

Для себорейної пухирчатки не характерне враження слизових оболонок. Дерматоз локалізується на обличчі еритематозні та гіперпігментовані плями, вкриті лусочками, що нагадують «метелика», як при дискоїдному червоному вовчаку. В'ялі пухирі можуть вкривати шкіру волосистої частини голови та шкіру тулуба (себорейні ділянки). Порушення цілісності призводить до мокнуття, ерозії вкриваються багатошаровими серозно-геморагічними кірками. Слизова оболонка вражається вкрай рідко.

Листоподібна пухирчатка, як і себорейна, характеризується формуванням елементів, в першу чергу в себорейних ділянках (волосиста частина голови, обличчя, верхня третина тулуба). Пухирі з в'ялою покришкою, швидко втрачають цілісність. Ерозії, які формуються 
після розриву пухиря, вкриваються кірочками. Для листоподібної пухирчатки, на відміну від себорейної, характерне формування нового міхура під кірочкою - в місці попередньої ерозії. Клінічна картина листоподібної та себорейної пухирчатки дуже схожа на себорейний дерматит, дискоїдний червоний вовчак, екзему, псоріаз, а в разі приєднання вторинної інфекції - піодермію та вульгарну ектіму.

Наступна форма - вегетуюча пухирчатка - найрідкісніша серед акантолітичних бульозних дерматозів, але не $є$ менш вивченою. Пухирі, які локалізуються в природних шкірних складках, втрачають цілісність і формують ерозивні вогнища, на яких розвиваються вегетації, поверхня яких зсихається, формуючи кірочки, - набуває вигляду бородавчатих нашарувань. Периферійний ріст вегетацій формує бляшки. До вегетуючої пухирчатки належать два типи: тип Аллопо, тип Нойманна. Первинним елементом вегетуючої пухирчатки типу Аллопо є пустула. Дерматоз має доброякісний перебіг і чутливий до терапії. Для типу Нойманна характерні пухирі на шкірі волосистої частини голови, обличчя, верхньої частини тулуба, природних складок. Таким хворим треба проводити диференційну діагностику з хронічною доброякісною сімейною пухирчаткою Гужеро-Хейлі-Хейлі, піогенною гранульомою, екземою тощо [2].

Під нашим спостереженням перебувала жінка М., 29 років, мешканка Донецької області, яка була направлена до клініки ДУ «ІДВ НАМНУ» зі скаргами на висип на шкірі обличчя, тулуба, верхніх і нижніх кінцівок, слизовій оболонці ротової порожнини, червоній облямівці губ і промежині, болючість у місцях висипу, труднощі під час прийому їжі та ковтання.

3 анамнезу хвороби відомо, що хворіє з травня 2018 р., коли з'явився висип на слизовій оболонці ротової порожнини після пломбування зубів полімерними пломбами. Восени була госпіталізована до інфекційного відділення у зв'язку з поширеністю процесу на слизовій оболонці ротової порожнини з діагнозом «Герпетичний стоматит». Лікування ефекту не мало. В грудні 2018 р. дерматоз вразив червону облямівку губ, шкіру обличчя, тулуба, верхніх і нижніх кінцівок. На консультації в ДУ «ІДВ НАМНУ» під час цитологічного дослідження були знайдені акантолітичні клітини. Встановлено діагноз «Вульгарна пухирчатка». Хворій запропонована госпіталізація та лікування в стаціонарі дерматологічного відділення.

Об'сктивно на момент госпіталізації загальний стан тяжкий: свідомість ясна, хвора виснажена з ознаками інтоксикації та гіпертермії, психоемоційно лабільна. Дерматоз мав дисемінований характер. Локалізувався на слизовій оболонці ротової порожнини та промежини, червоній облямівці губ, шкірі обличчя, тулуба, верхніх і нижніх кінцівок. На слизовій оболонці ротової порожнини (твердому та м'якому піднебінні, спинки та бокової поверхні язика, під’язиковій ділянці, слизовій щік і ясен) та зовнішніх статевих органів (малі та великі статеві губи, задня спайка) численні ерозивні дефекти розміром від 0,5 до 3,5 см у діаметрі, вкриті білим нальотом, обривки епітелію по периферії ерозій (рис. 1, 2). Червона облямівка губ вкрита масивними багатошаровими серозно-геморагічними кірками, що ускладнювало відкриття рота та прийом їжі. У кутах губ - лінійні тріщини, що кровоточать. На шкірі обличчя, навколо вушних раковин, грудної клітки, під молочними залозами, живота, спини, сідниць, лівої гомілки висип представлений пухирями розміром від 0,7 до 5,0 см у діаметрі, наповненими серозним умістом. Крайовий і віддалений симптом Нікольского різко позитивні, позитивні симптом Асбо - Хансена та Шеклакова. Ерозії овальної форми на незміненому тлі, подекуди зливаються між собою, розміром від 0,5 до 7,0 см у діаметрі, 3 масивними серозно-геморагічними нашаруваннями кірочок. Зона біля нігтьового валика 1-, 2- та 4-го пальців лівої та правої кистей набрякла, гіперемована. В разі натискання на нігтьове ложе виділяється гнійний секрет. Вага під час госпіталізації становила 49 кг.

Клініко-лабораторні дослідження під час госпіталізації: клінічний аналіз крові, клінічний аналіз сечі, біохімічний аналіз крові, показники системи згортання крові - в межах норми. Звертало увагу: цитологічне дослідження з дна пухиря на лівій гомілці - виявлені акантолітичні клітини, що розташовані поодиноко та скупченнями. Запальний інфільтрат скудний.

Лікувальна схема охоплювала: системну глюкокортикостероїдну терапію - дексаметазон по 2,0 внутрішньом'язево, полькортолон у дозі 16 мг/добу з поступовим iii зниженням до 13 мг/добу, медрол по 8 мг/добу; цитостатичну терапію - імуран у дозі 50 мг/добу; антибактеріальну та антимікотичну терапію, ад’ювантну терапію, інгібітори протонної помпи та симптоматичну терапію. Зовнішня терапія полягала в полосканні ротової порожнини, ванночках $з$ антисептичними та дезінфекційними розчинами, застосуванні водних анілінових барвників, ранозагоювальних місцевих препаратів.

Дерматоз регресував, хвора виписана в стані клінічної ремісії на дозі полькортолону 13 мг/добу з поступовим

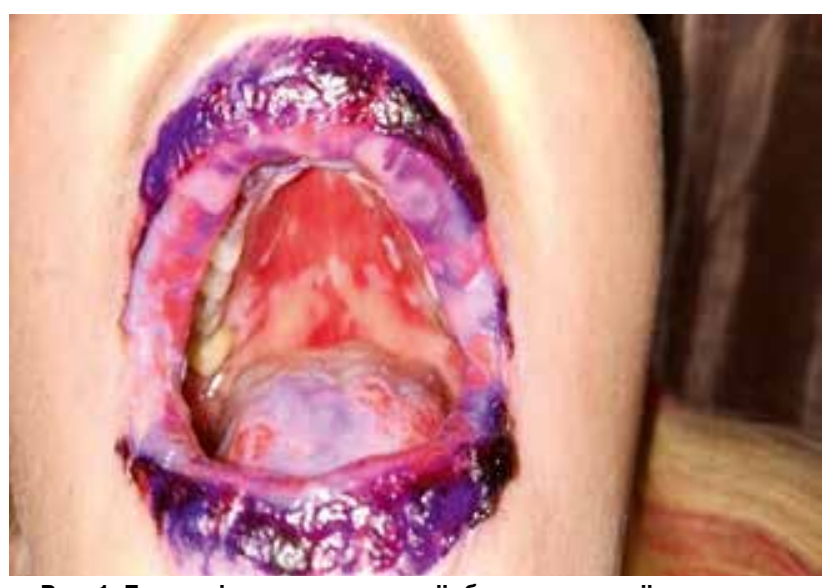

Рис. 1. Ерозивні ураження слизової оболонки ротової порожнини, червоної облямівки губ хворої М. до лікування

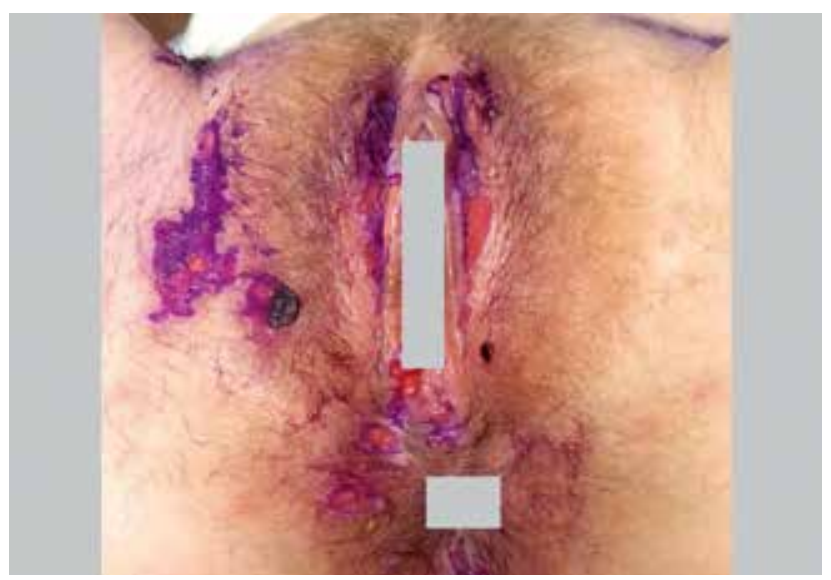

Рис. 2. Ерозивні ураження зовнішніх статевих органів хворої М. до лікування 
iii зниженням до 8 мг/добу по 1 мг кожні 3 дні, медрол у дозі 8 мг/добу, імуран по 50 мг/добу (рис. 3-5). Рекомендовано наступне зниження дози глюкокортикостероїдів і цитостатика під наглядом дерматолога за місцем проживання. На момент виписки вага хворої становила 55 кг.

Слід зауважити, що діагноз в даному випадку був встановлений завдяки клінічним ознакам і підтверджений за допомогою цитологічного дослідження мазка-відбитка з дна пухиря. Біопсійне дослідження та гістологічний аналіз матеріалу, дослідження матеріалу за допомогою прямої імунофлюоресценції, імуно-ферментного аналізу з визначенням титру антитіл до десмоглеїну-1 та десмоглеїну-3 на сьогодні забезпечують найбільш достовірний результат під час встановлення та підтвердження діагнозу.

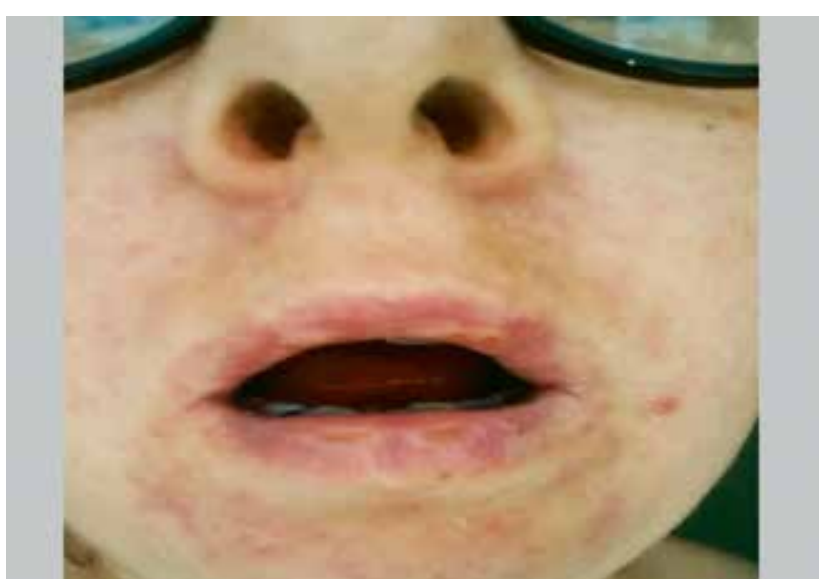

Рис. 3. Регрес клінічних проявів на червоній облямівці губ хворої М. на момент виписки

\section{Список літератури}

1. Альбанова В.И., Нефедова М.А. Аутоиммунные буллезные дерматозы. Дифференциальный диагноз. Вестник дерматологии и венерологи. 2017. № 3. С. 10

2. Кубанова А.А., Акимов В.Г. Дифференциальная диагностика и лечение кожных болезней. М.: МИА, 2009.

3. К вопросу о классификации буллезных дерматозов / С.Б. Ткаченко, Н.П. Теплюк, А.С. Алленова, А.А. Лепехова. Российский журнал кожных и венерических болезней. 2015. № 2. T. 18(2). С. 11-14.

4. Рубинс А. Дерматовенерология. Иллюстрированное руководство. М.: Издательство Панфилова, 2011.

5. Dermatology. Color Atlas and Synopsis / T. Fitzpatrick, R. Johnson, K. Wolff, M. Polano, D. Suurmond. 1999.

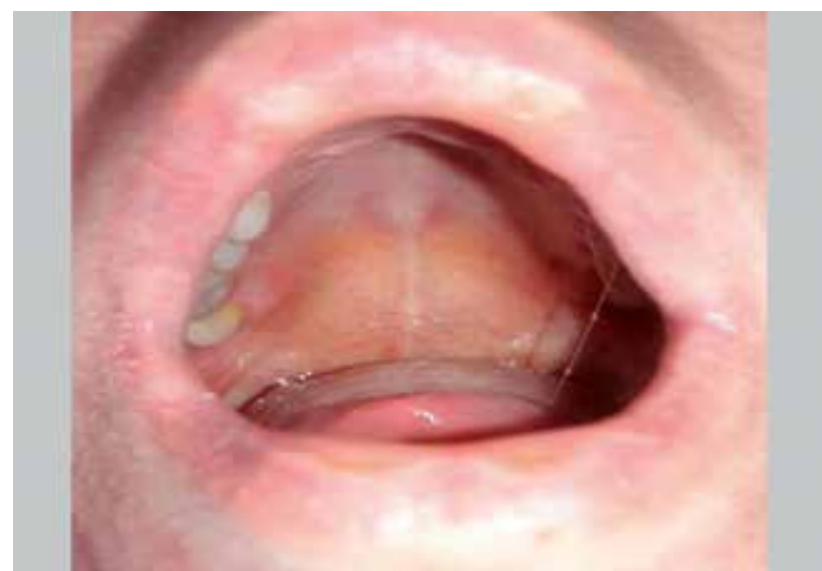

Рис. 4. Регрес клінічних проявів на слизовій оболонці ротової порожнини хворої М. на момент виписки

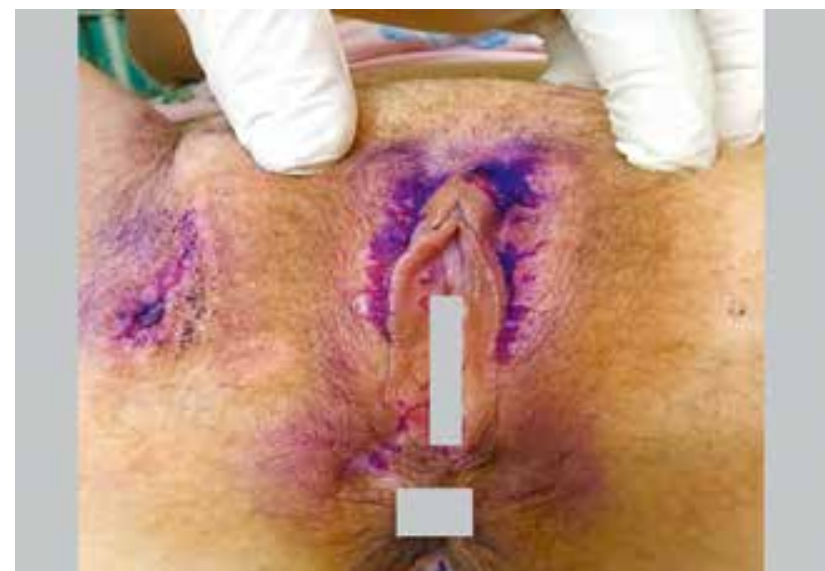

Рис. 5. Регрес клінічних проявів у ділянці зовнішніх статевих органів хворої М. на момент виписки

\section{References}

1. Al'banova VI, Nefedova MA. Autoimmunnyie bulleznyie dermatozyi. Differentsialnyiy diag noz [Autoimmune bullous dermatoses. Differential diagnosis]. Vestnik dermatologii i venerologii. 2017;(3): 10-20. (In Russ.)

2. Kubanova AA, In Akimov D. Differentsialnaya diagnostika i lechenie kozhnyih bolezney [Differential diagnosis and treatment of skin diseases]. M.: MIA; 2009. (In Russ.)

3. Tkachenko SB, Teplyuk NP, Allenova AS, Lepekhova AA. K voprosu o klassifikatsii bulleznyih dermatozov [On classification of bullous dermatosis]. Rossiyskiy zhurnal kozhnykh i venericheskikh bolezney. 2015;18(2):11-14. (in Russ.)

4. Rubins A. Dermatovenerologiya. Illyustrirovannoe rukovodstvo [Dermatovenerology. Illustrated guide]. M.: Panfilov Publishing House, 2011. (in Russ.)

5. Fitzpatrick T, Johnson R, Wolff K, Polano M, Suurmond D. Dermatology. Color Atlas and Synopsis, 1999.

\section{МЕСТО КЛИНИЧЕСКИХ И ДИАГНОСТИЧЕСКИХ ИССЛЕДОВАНИЙ АКАНТОЛИТИЧЕСКОГО ПЕМФИГУСА}

\section{И.А. Олейник, А.Э-С.Э-С. Абдалла}

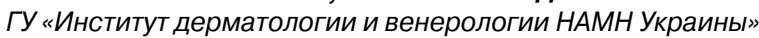

\section{Резюме}

В работе представлен случай вульгарной пузырчатки, клиническая картина заболевания, методы исследования, а также указана лечебная тактика.

Ключевые слова: вульгарная пузырчатка, течение, диагностика, лечение.

\section{LOCATION OF CLINICAL AND DIAGNOSTIC STUDIES OF ACANTHOLYTIC PEMPHIGUS}

\section{I.O. Oliinyk, A.E-S.E-S.Abdalla}

SE «Institute of Dermatology and Venereology of NAMS of Ukraine»

\section{Abstract}

The paper presents the case of the pemphigus vulgaris, the clinical picture of the disease, the methods of research and the indicated therapeutic tactics.

Key words: pemphigus vulgaris, current, diagnosis, treatment.

\section{Відомості про авторів:}

Олійник Ірина Олександрівна - д-р мед. наук, ст. наук. співроб., головний наук. співроб. відділу дерматології, інфекційних та паразитарних захворювань шкіри ДУ «Інститут дерматології та венерології НАМН України».

Абдалла Алія Ель-Саед Ель-Седик - аспірант відділу дерматології, інфекційних та паразитарних захворювань шкіри ДУ «Інститут дерматології та венерології НАМН України». 